\title{
Comparative effects of EGCG, green tea and a nutrient mixture on the patterns of MMP-2 and MMP-9 expression in cancer cell lines
}

\author{
M.W. ROOMI, J.C. MONTERREY, T. KALINOVSKY, M. RATH and A. NIEDZWIECKI \\ Dr Rath Research Institute, 1260 Memorex Drive, Santa Clara, CA 95050, USA
}

Received May 18, 2010; Accepted June 21, 2010

DOI: $10.3892 /$ or_00000917

\begin{abstract}
Type IV collagenase matrix metalloproteinases (MMPs), especially MMP-2 and MMP-9, have been found to promote invasion and metastasis of malignant tumors. Extracellular matrix (ECM) degradation by MMPs and increased expression of MMPs in cancer cells and tumor microvascular endothelial cells make MMPs an attractive target for cancer. Focused on a common pathomechanism of cancer growth and invasion, the disintegration of connective tissue, we used natural approaches to increase the integrity and strength of connective tissues. Utilizing the principle of nutrition synergy, we developed a novel micronutrient mixture (NM) containing lysine, proline, ascorbic acid and green tea extract. This study evaluates the potency of the components EGCG and green tea extract independently compared to that of NM on modulation of patterns of MMP-2 and MMP-9 expression in four cancer cell lines expressing MMP-2, MMP-9 or both. Human fibrosarcoma (HT-1080), hepatocellular carcinoma (SKHep-1), glioblastoma (T-98G), uterine leiomyosarcoma (SKUT-1) cell lines were obtained from ATCC and grown in minimum essential medium (MEM) supplemented with $10 \%$ FBS, penicillin $(100 \mathrm{U} / \mathrm{ml})$ and streptomycin $(100 \mathrm{mg} / \mathrm{ml})$ in 24-well tissue culture plates. At near confluence, the cells were treated with agents dissolved in media and tested at concentrations indicated in triplicate at each dose. Cells were also treated with PMA $100 \mathrm{ng} / \mathrm{ml}$ to study enhanced expression of MMP-9. MMP expression was assessed by gelatinase zymography. Fibrosarcoma and hepatocellular carcinoma cells expressed both MMP-2 and MMP-9. Glioblastoma cells expressed MMP-2 and PMA treatment induced MMP-9 expression. Uterine leimyosarcoma cells expressed no MMPs but PMA induced MMP-9. NM was the most potent dosedependent inhibitor of MMPs, followed by green tea extract and EGCG. In conclusion, these results suggest the enhanced efficacy of nutrients working in synergy to modulate complex pathways such as MMP expression.
\end{abstract}

Correspondence to: Dr Aleksandra Niedzwiecki, Dr Rath Research Institute, 1260 Memorex Drive, Santa Clara, CA 95050, USA E-mail: author@drrath.com

Key words: EGCG, green tea, nutrient mixture, MMP-2, MMP-9

\section{Introduction}

Metastasis is responsible for a majority of cancer-related deaths. Tumor invasion of surrounding tissue and subsequent metastasis results from a multi-step process that includes proteolytic degradation of the surrounding extracellular matrix (ECM), allowing malignant cells to move into and through the ECM and basement membrane (1-5). Type IV collagenase matrix metalloproteinases (MMPs), in particular, MMP-2 and MMP-9, gelatinase A and B, respectively, have been found to promote invasion and metastasis of malignant tumors $(4,5)$. Elevated levels of MMP-2 and MMP-9 are often correlated with malignancies of liver $(6,7)$, brain $(8)$, breast (9), prostate (10), cervical (11), ovarian (12) and other cancers. Degradation of the ECM by MMPs and the increased expression of MMPs associated with tumor growth, angiogenesis and metastasis point to MMPs as an attractive target for cancer treatment.

We focused on a common pathomechanism of cancer growth and invasion, disintegration of connective tissue, and have developed strategies to inhibit cancer development by inhibiting MMPs, especially MMP-2 and MMP-9 using natural products. Focusing on natural approaches to increase the integrity and strength of connective tissues and utilizing the principle of synergy, we combined lysine, proline, ascorbic acid and green tea extract among other micronutrients to develop a novel micronutrient mixture (NM).

The micronutrient mixture has been shown to inhibit MMP expression in a number of cancer cell lines $(13,14)$. It also exhibited a broad spectrum of anti-tumor activity against a number of cancer cell lines, including inhibition of cell proliferation, cell invasion, anti-metastatic potential, inhibition of angiogenesis and pro-apoptotic effects against a number of human cancer cell lines in vitro and in vivo (15-17).

The NM was formulated by selecting nutrients that act on critical physiological targets in cancer progression and metastasis. Adequate supplies of ascorbic acid and the amino acids lysine and proline are essential for optimal ECM formation and structure, as these nutrients ensure proper synthesis and hydroxylation of collagen fibers. Lysine also contributes to ECM stability as a natural inhibitor of plasmin-induced proteolysis $(18,19)$. Manganese and copper are also essential for collagen formation. Green tea extract has been shown to modulate cancer cell growth, metastasis, angiogenesis and other aspects of cancer progression (20-26). N-acetyl cysteine 
Table I. NM equivalents in test solutions.

\begin{tabular}{lcccccc}
\hline Treatment/Stock solution no. & 0 & 1 & 2 & 3 & 4 & 5 \\
\hline Nutrient mixture $(\mu \mathrm{g})$ & 0 & 50 & 100 & 250 & 500 & 1000 \\
EGCG equivalent $(\mu \mathrm{g})$ & 0.0000 & 3.8308 & 7.6617 & 19.154 & 38.309 & 76.617 \\
GTE equivalent $(\mu \mathrm{g})$ & 0.0000 & 8.7562 & 17.512 & 43.781 & 87.562 & 175.12 \\
\hline
\end{tabular}

and selenium have been observed to inhibit MMP-9 and invasive activities of tumor cells, as well as migration of endothelial cells through ECM (27-31). Ascorbic acid has been demonstrated to inhibit tumor growth via anti-angiogenic activity (32) and to inhibit cell division and growth in vitro through production of hydrogen peroxide (33). Arginine is a precursor of nitric oxide (NO); any deficiency of arginine can limit the production of NO, which has been shown to predominantly act as an inducer of apoptosis, as in breast cancer cells (34).

In this study we examined the relative inhibitory effects on MMP-2 and MMP-9 of epigallocatechin gallate (EGCG), the main polyphenol in green tea extract (GTE) to that of green tea extract and the nutrient mixture as a whole on several cancer cell lines to elucidate whether there is an additive or synergistic effect from combination of these agents.

\section{Materials and methods}

Cancer cell line and culture. Human fibrosarcoma (HT1080), hepatocellular carcinoma (SK-Hep-1), glioblastoma (T-98G) and uterine leiomyosarcoma (SK-UT-1) cell lines and their recommended media, minimum essential medium (MEM), were obtained from ATCC (American Type Culture Collection, Rockville, MD). Cells were maintained in MEM supplemented with $10 \%$ fetal bovine serum, $100 \mathrm{U} / \mathrm{ml}$ penicillin and $100 \mu \mathrm{g} / \mathrm{ml}$ streptomycin in 24-well tissue culture plates (Costar, Cambridge, MA). Cells were incubated with $1 \mathrm{ml}$ of media at $37^{\circ} \mathrm{C}$ in a tissue culture incubator equilibrated with $95 \%$ air and $5 \% \mathrm{CO}_{2}$. At near confluence, the cells were treated with the nutrient mixture, green tea extract, epigallocatechin gallate or other agents dissolved in media and tested at the concentrations indicated in triplicate at each dose. The media and sera used were obtained from ATCC, and antibiotics (penicillin and streptomycin) were from Gibco BRL, Long Island, NY. EGCG and other chemicals were obtained from Sigma.

Composition of the nutrient mixture. The nutrient mixture was composed of the following in the ratio indicated: Vitamin $\mathrm{C}$ (as ascorbic acid and as $\mathrm{Mg}, \mathrm{Ca}$ and palmitate ascorbate) $700 \mathrm{mg}$, L-lysine $1000 \mathrm{mg}$, L-proline $750 \mathrm{mg}$, L-arginine $500 \mathrm{mg}$, N-acetyl cysteine $200 \mathrm{mg}$, standardized green tea extract [derived from green tea leaves, was obtained from US Pharma Lab; the certificate of analysis indicated the following characteristics: total polyphenol $80 \%$, catechins $60 \%$, epigallocatechin gallate (EGCG) 35\% and caffeine $1.0 \%$ ] $1000 \mathrm{mg}$, selenium $30 \mu \mathrm{g}$, copper $2 \mathrm{mg}$, manganese $1 \mathrm{mg}$. Stock solutions of GTE and EGCG were prepared as nutrient mixture equivalents in the composition of NM. The respective amounts for each equivalent of NM are indicated in Table I.

In addition, the following components of NM were tested at one dose only - the equivalent of their concentration in $1000 \mu \mathrm{g} / \mathrm{ml}$ NM. A combination of $400 \mu \mathrm{M}$-lysine, $120 \mu \mathrm{M}$ proline, $100 \mu \mathrm{M}$-AA (LPA); N-acetyl cysteine (NAC) at $43.8 \mu \mathrm{g}$; and L-selenomethionine at $1.3 \mu \mathrm{g}$.

Gelatinase zymography. MMP expression in conditioned media was determined by gelatinase zymography. Gelatinase zymography was performed in $10 \%$ Novex Pre-Cast SDS Polyacrylamide Gel (Invitrogen Corp.) in the presence of $0.1 \%$ gelatin under non-reducing conditions. Culture media (20 $\mu \mathrm{l})$ were mixed with sample buffer and loaded for SDSPAGE with tris glycine SDS buffer as suggested by the manufacturer (Novex). Samples were not boiled before electrophoresis. Following electrophoresis the gels were washed twice in $2.5 \%$ Triton $\mathrm{X}-100$ for $30 \mathrm{~min}$ at room temperature to remove SDS. The gels were then incubated at $37^{\circ} \mathrm{C}$ overnight in substrate buffer containing $50 \mathrm{mM}$ Tris- $\mathrm{HCl}$ and $10 \mathrm{mM} \mathrm{CaCl} 2$ at $\mathrm{pH} 8.0$ and stained with $0.5 \%$ Coomassie Brilliant Blue R250 in 50\% methanol and 10\% glacial acetic acid for $30 \mathrm{~min}$ and destained. Upon renaturation of the enzyme, the gelatinases digest the gelatin in the gel and give clear bands against an intensely stained background. Protein standards were run concurrently and approximate molecular weights were determined by plotting the relative mobilities of known proteins.

Gelatinase zymograms were scanned using CanoScan 9950F Canon Scanner at $300 \mathrm{dpi}$. The intensity of the bands was evaluated using the pixel-based densitometer program Un-Scan-It, Version 5.1, 32-bit, by Silk Scientific Corp. (Orem, UT, USA), at a resolution of 1 Scanner Unit (1/100 of an inch for an image that was scanned at $100 \mathrm{dpi}$ ). The pixel densitometer calculates the optical density of each pixel (values 0-255) using the darkly stained background of the gel as a pixel value of 0 . A logarithmic optical density scale was used since the optical density of films and gels is logarithmically proportional to the concentration. The pixel densitometer sums the optical density of each pixel to give a band's density. In all graphs, band densities were reported as percentages of the sums of all pixels in a given lane (treatment) of a gel.

The effect of EGCG, GTE and NM on MMP expression was assessed by treating cells to increasing concentrations of EGCG, GTE and NM and expressed as relative band densities (as \% of control value). The cumulative effect of EGCG, GTE or NM, was determined by summing all the band densities 
A) Fibrosarcoma (HT-1080)

C) Glioblastoma (T-98G)

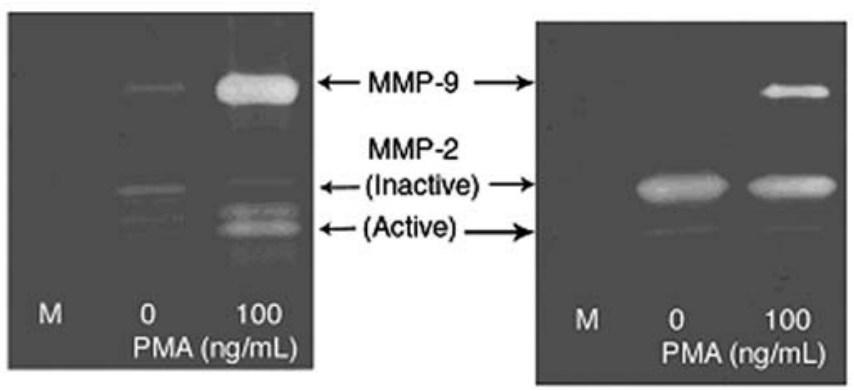

B) Hepatocellular Carcinoma (SK-Hep-1)

D) Uterine Leiomyosarcoma (Sk-Ut-1)

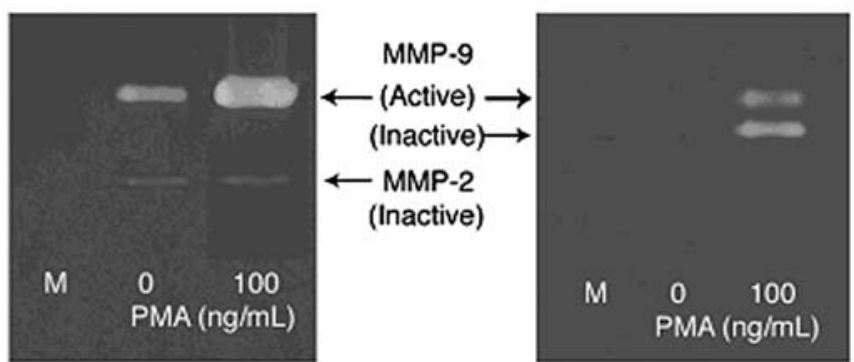

Figure 1. Zymograms of MMP-2 and MMP-9 expression by fibrosarcoma HT-1080 (A), hepatocellular carcinoma SK-Hep-1 (B), glioblastoma T-98G (C) and uterine leiomyosarcoma SK-UT-1 (D).

within a treatment group, and comparing these densities between treatment groups. The extent of total MMP band expression in a treatment group was reported as 'total band pixels'.

\section{Results and Discussion}

MMP-2 and MMP-9 expression in normal and PMA-treated fibrosarcoma, hepatocellular carcinoma, glioblastoma and uterine leiomyosarcoma cell lines. Hepatocellular carcinoma SK-Hep-1 exhibited a major band at $92 \mathrm{kDa}$ for MMP-9 and a faint band at $72 \mathrm{kDa}$ for MMP-2, whereas human glioblastoma cell line T-98G had only one band, with molecular weight corresponding to MMP-2. Uterine leiomyosarcoma SK-UT-1 did not express MMP-2 or MMP-9 in untreated conditioned media. PMA treatment of the cell lines induced MMP-9. Fibrosarcoma HT-1080 showed MMP-9 (92 kDa) as a major band and MMP-2 $(72 \mathrm{kDa})$ as a minor band with PMA treatment. With PMA treatment, MMP-9 expression was increased in SK-Hep-1, and in T-98G, PMA led to the expression of both MMP-2 and MMP-9 in equal intensities. Interestingly, SK-UT-1, on PMA treatment, exhibited both active and inactive MMP-9 in equal proportions. The MMP profiles of these cancer cell lines are depicted in Fig. 1.

Effect of lysine, proline, ascorbic acid, NAC and selenium on $M M P$ expression. Initially we investigated the effect of a combination of NM components $400 \mu \mathrm{M}$-lysine $+120 \mu \mathrm{M}$ proline $+100 \mu \mathrm{M}-\mathrm{AA}$ (LPA), the equivalent concentration of these agents in NM $1000 \mu \mathrm{g} / \mathrm{ml}$, on MMP expression in conditioned and PMA-stimulated media. LPA had no effect on expression of either MMP-2 or MMP-9 in all four cell lines, regardless of PMA treatment at the dose tested. We also studied the effect of NM components $\mathrm{N}$-acetyl cysteine (NAC) and selenium on MMP expression in both uninduced and induced media. As shown in Figs. 2 and 3, neither NAC nor selenium had any effect on MMP-2 and MMP-9 expression at the dose tested. Figs. 2 and 3 present the zymograms and densitometric analyses for results from treatment of SK-Hep-1 and human glioblastoma cell lines with LPA, NAC and Se.

Effect of NM, GTE and EGCG on MM-2 and MMP-9 secretion. Our next step was to explore the comparative effects of NM to that of green tea extract (GTE), an important constituent of the nutrition mixture and EGCG, because EGCG is the main constituent of green tea. The green tea extract and EGCG solutions were prepared to match the equivalent amount found in 50,100, 250, 500 and $1000 \mu \mathrm{g} / \mathrm{ml}$ concentrations of nutrition mixture.

Effect of NM, GTE and EGCG on MMP-2 and -9 secretion by fibrosarcoma cells. Fibrosarcoma (HT-1080) cells expressed both MMP-2 and MMP-9, and the nutrient mixture was the most potent dose-dependent inhibitor of both MMPs, followed by green tea extract and then EGCG, as shown in Fig. 4 and Table II. Although EGCG and green tea extract greatly reduced MMP-2 expression at $100 \mu \mathrm{g} / \mathrm{ml}$ equivalent of NM, they did not completely block MMP-2 expression. However, the nutrient mixture at $100 \mu \mathrm{g} / \mathrm{ml}$ concentration completely abolished MMP-2 expression. MMP-9 expression decreased in a dose-dependent fashion with EGCG, GTE and NM treatment, but only GTE and NM were able to completely abolish MMP-9 expression at $500 \mu \mathrm{g} / \mathrm{ml}$. Treating the fibrosarcoma cell line with PMA induced further MMP-9 expression, but the inhibitory effects of EGCG, GTE and the NM on the expression of MMP-2 and MMP-9 was generally the 
A

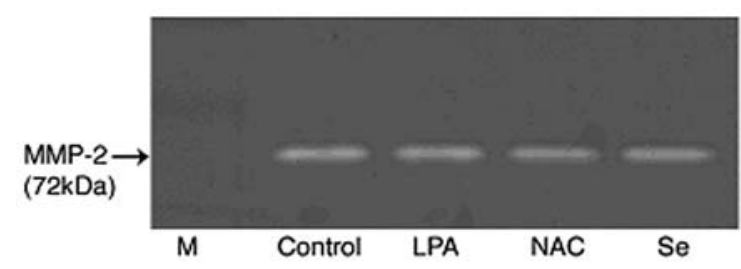

C

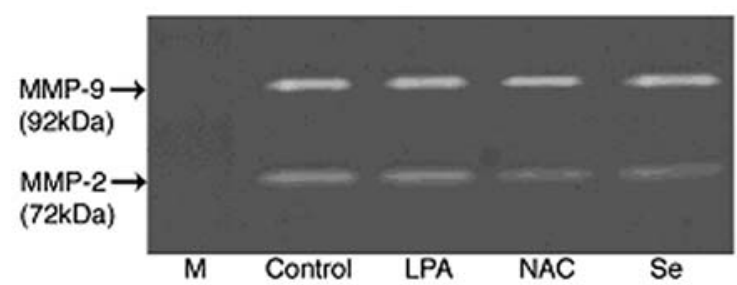

B

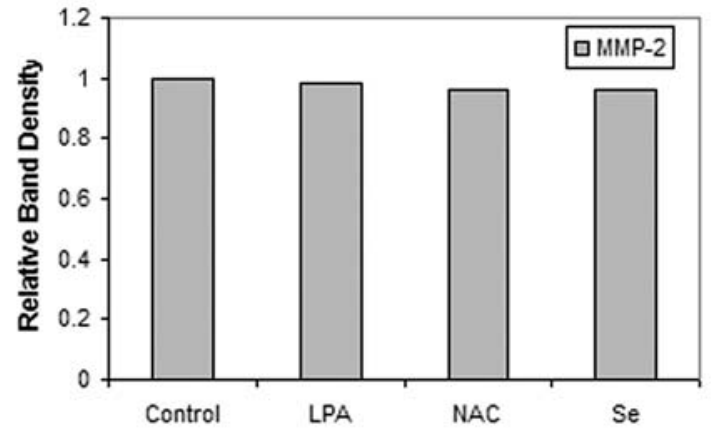

D

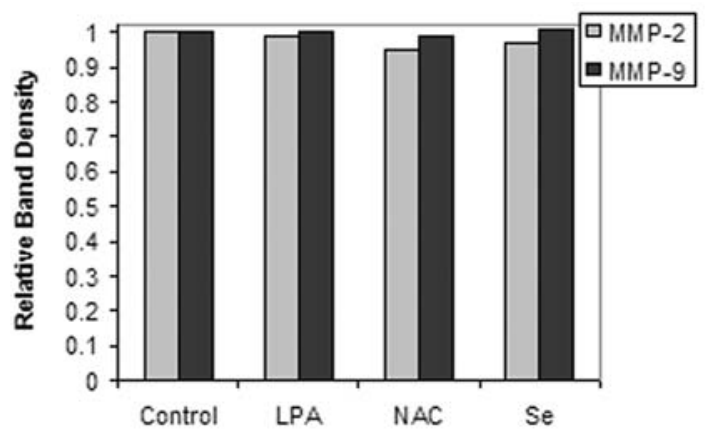

Figure 2. Effect of LPA, NAC and Se on MMP-2 and MMP-9 expression in PMA-treated and non-treated human gliobalstoma cells. (A) Gelatinase zymogram of T-98G cells showing no effect of any of the tested agents on MMP-2 expression. (B) Quantitative densitometry showing no effect of tested agents on T98G cell MMP-2 expression. (C) Gelatinase zymogram of PMA (100 ng/ml)-treated T-98G cells showing MMP-9 induction with PMA treatment and no effect of any of the agents tested on MMP-2 or MMP-9 expression. (D) Quantitative densitometry showing no effect of tested agents on PMA-treated T-98G cell MMP-2 or MMP-9 expression.

A

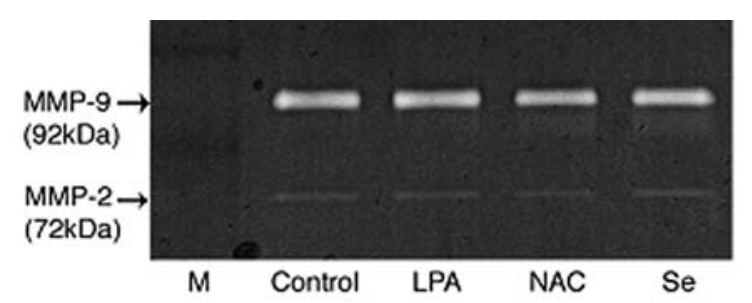

C

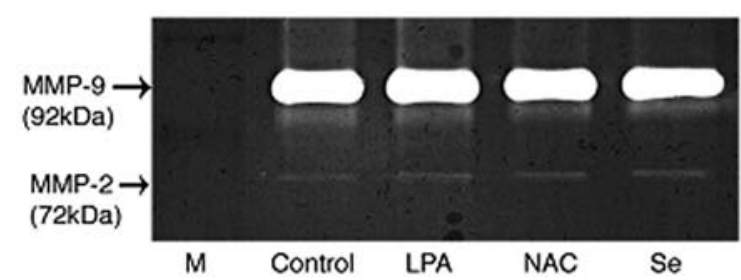

B

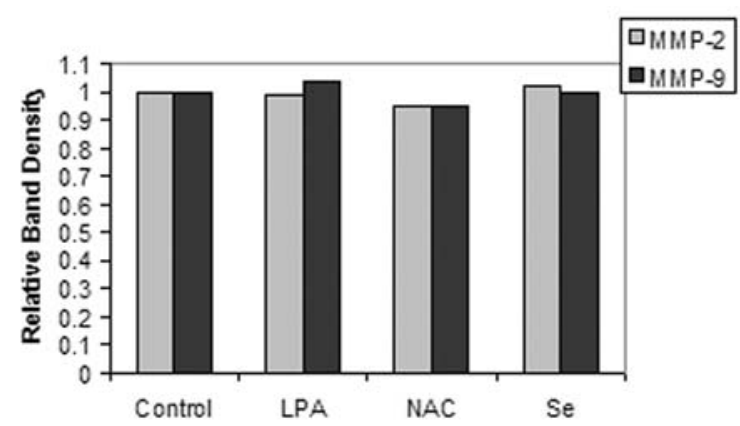

D

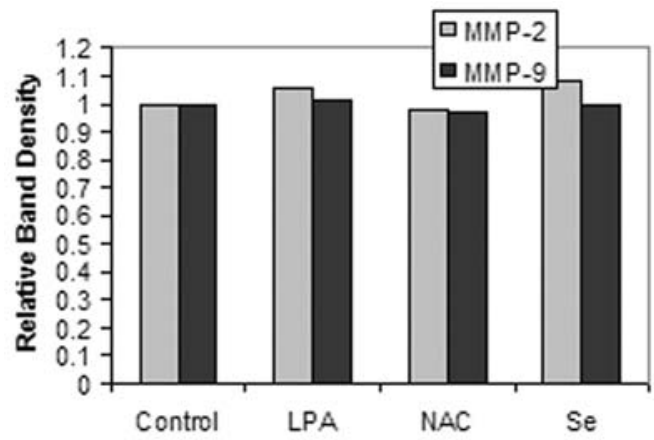

Figure 3. Effect of LPA, NAC and Se on MMP-2 and MMP-9 expression in PMA-treated and non-treated human hepatocellular carcinoma cells. (A) Gelatinase zymogram of SK-Hep-1 cells showing no effect of any of the tested agents on MMP-2 or MMP-9 expression. (B) Quantitative densitometry showing no effect of tested agents on SK-Hep-1 cell MMP-2 and MMP-9 expression. (C) Gelatinase zymogram of PMA (100 ng/ml)-treated SK-Hep-1 cells showing increased MMP-9 expression with PMA treatment and no effect of any of the agents tested on MMP-2 or MMP-9 expression. (D) Quantitative densitometry showing no effect of tested agents on PMA-treated SK-Hep-1 cell MMP-2 or MMP-9 expression.

same, as shown in Fig. 5 and Table II. The nutrient mixture was the most potent dose-dependent inhibitor of MMP expression, followed by green tea extract and then EGCG.
MMP-2 appeared to be more sensitive to MMP inhibition by inhibitor treatment than MMP-9 in PMA treated cells (MMP-2 expression was abolished by $50 \mu \mathrm{g} / \mathrm{ml}$ with the nutrient 
$\mathbf{A}$

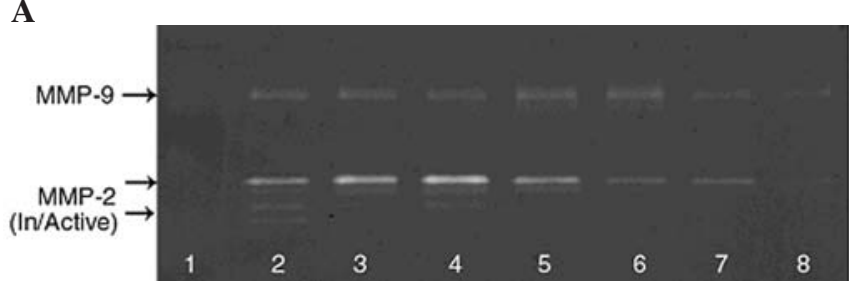

C

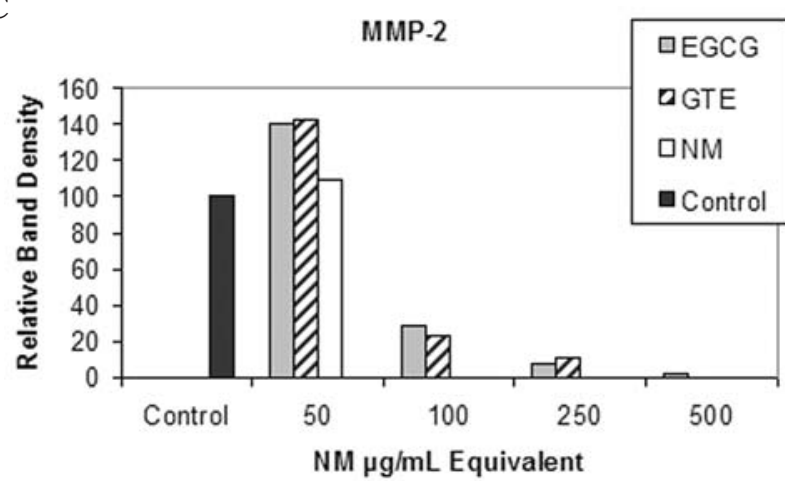

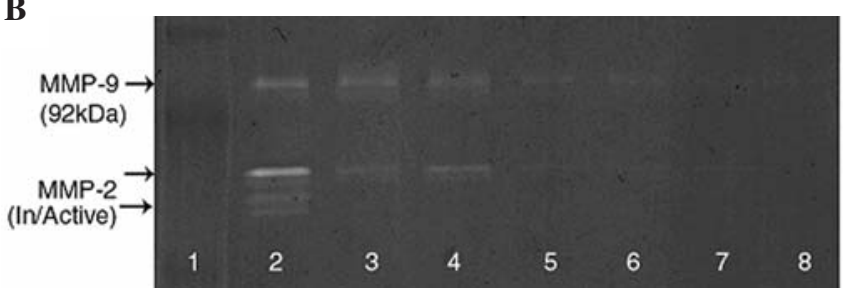

D

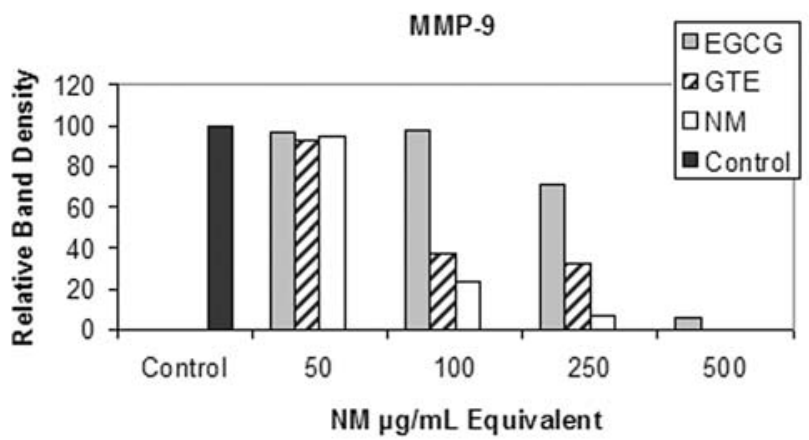

Figure 4. Comparative effects of EGCG, GTE and NM on MMP-2 and MMP-9 expression of normal human fibrosarcoma HT-1080 cells. (A, B) Gelatinase zymogram of HT-1080 cells showing dose-dependent inhibition of MMP-2 and MMP-9 expression; NM was the most potent followed by GTE and EGCG. (A) Legend: 1-Markers, 2-control, 3-5, $50 \mu \mathrm{g} / \mathrm{ml} \mathrm{NM} \mathrm{EQ} \mathrm{of} \mathrm{EGCG,} \mathrm{GTE} \mathrm{and} \mathrm{NM,} \mathrm{respectively;} \mathrm{6-8,} 100 \mu \mathrm{g} / \mathrm{ml} \mathrm{NM} \mathrm{EQ} \mathrm{of} \mathrm{EGCG,} \mathrm{GTE} \mathrm{and} \mathrm{NM,}$ respectively. (B) Legend: 1-Markers, 2-control, 3-5, $250 \mu \mathrm{g} / \mathrm{ml}$ NM EQ of EGCG, GTE and NM, respectively; 6-8, 500 $\mu \mathrm{g} / \mathrm{ml}$ NM EQ of EGCG, GTE and NM, respectively. (C, D) Quantitative densitometry showing comparative effects of NM, GTE and EGCG on HT-1080 cell (C) MMP-2 and (D) MMP-9 expression.

Table II. Effect of EGCG, GTE and NM on MMP-2 and -9 secretion by fibrosarcoma (HT-1080).

\begin{tabular}{|c|c|c|c|}
\hline \multicolumn{2}{|c|}{ Without PMA } & \multicolumn{2}{|c|}{$\begin{array}{l}\text { With PMA } \\
(100 \mathrm{ng} / \mathrm{ml})\end{array}$} \\
\hline $\begin{array}{c}\text { MMP-2 } \\
(\%)\end{array}$ & $\begin{array}{c}\text { MMP-9 } \\
(\%)\end{array}$ & $\begin{array}{c}\text { MMP-2 } \\
(\%)\end{array}$ & $\begin{array}{c}\text { MMP-9 } \\
(\%)\end{array}$ \\
\hline
\end{tabular}

$\operatorname{EGCG}(\mu \mathrm{g} / \mathrm{ml})$

$\begin{array}{rrrrr}0 & 100 & 100 & 100 & 100 \\ 50 & 140 & 96.5 & 71 & 120 \\ 100 & 29 & 98 & 0 & 120 \\ 250 & 8 & 70.6 & 0 & 74.7 \\ 500 & 2 & 6.2 & 0 & 19.8\end{array}$

$\operatorname{GTE}(\mu \mathrm{g} / \mathrm{ml})$

$\begin{array}{rrrrr}0 & 100 & 100 & 100 & 100 \\ 50 & 143 & 93 & 70 & 104 \\ 100 & 23 & 37 & 0 & 58.6 \\ 250 & 11 & 33 & 0 & 53.6 \\ 500 & 0 & 6.2 & 0 & 6.24\end{array}$

Nutrient mixture $(\mu \mathrm{g} / \mathrm{ml})$

\begin{tabular}{rrrrr}
0 & 100 & 100 & 100 & 100 \\
50 & 109 & 95 & 0 & 96.7 \\
100 & 0 & 23.7 & 0 & 26.2 \\
250 & 0 & 7.4 & 0 & 19.5 \\
500 & 0 & 0 & 0 & 0 \\
\hline
\end{tabular}

Table III. Effect of EGCG, GTE and NM on MMP-2 and -9 secretion by hepatocellular carcinoma (SK-Hep-1).

\begin{tabular}{|c|c|c|c|c|}
\hline & \multicolumn{2}{|c|}{ Without PMA } & \multicolumn{2}{|c|}{$\begin{array}{l}\text { With PMA } \\
(100 \mathrm{ng} / \mathrm{ml})\end{array}$} \\
\hline & $\begin{array}{l}\text { MMP-2 } \\
(\%)\end{array}$ & $\begin{array}{l}\text { MMP-9 } \\
(\%)\end{array}$ & $\begin{array}{l}\text { MMP-2 } \\
(\%)\end{array}$ & $\begin{array}{c}\text { MMP-9 } \\
(\%)\end{array}$ \\
\hline \multicolumn{5}{|c|}{$\mathrm{EGCG}(\mu \mathrm{g} / \mathrm{ml})$} \\
\hline 0 & 100 & 100 & 100 & 100 \\
\hline 50 & 197 & 114 & 45 & 69.7 \\
\hline 100 & 0 & 25.1 & 12.8 & 59 \\
\hline 250 & 0 & 0.6 & 0 & 65.8 \\
\hline 500 & 0 & 1.4 & 0 & 56 \\
\hline \multicolumn{5}{|c|}{ GTE $(\mu \mathrm{g} / \mathrm{ml})$} \\
\hline 0 & 100 & 100 & 100 & 100 \\
\hline 50 & 179 & 99.6 & 41 & 79.6 \\
\hline 100 & 0 & 1.9 & 0 & 55.2 \\
\hline 250 & 0 & 0.5 & 0 & 58.1 \\
\hline 500 & 0 & 1.0 & 0 & 46 \\
\hline \multicolumn{5}{|c|}{$\begin{array}{l}\text { Nutrient mixture } \\
(\mu \mathrm{g} / \mathrm{ml})\end{array}$} \\
\hline 0 & 100 & 100 & 100 & 100 \\
\hline 50 & 0 & 11.7 & 21.5 & 62.1 \\
\hline 100 & 0 & 1.9 & 0 & 50 \\
\hline 250 & 0 & 0.9 & 0 & 32.2 \\
\hline 500 & 0 & 0 & 0 & 0 \\
\hline
\end{tabular}


A

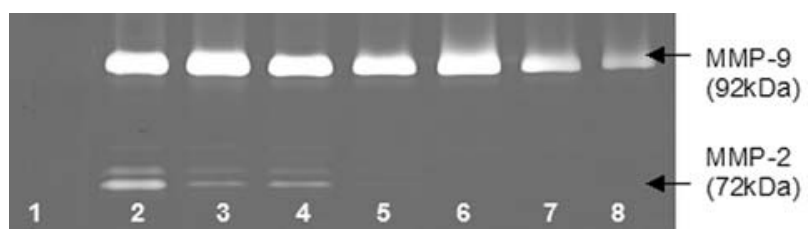

C

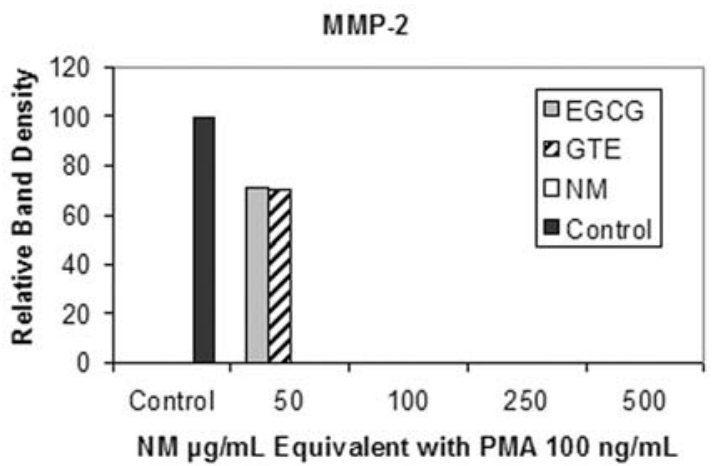

B

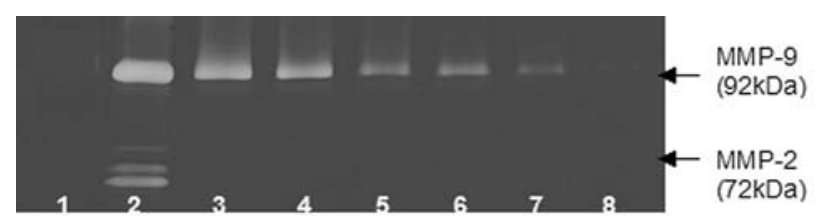

D

MMP-9

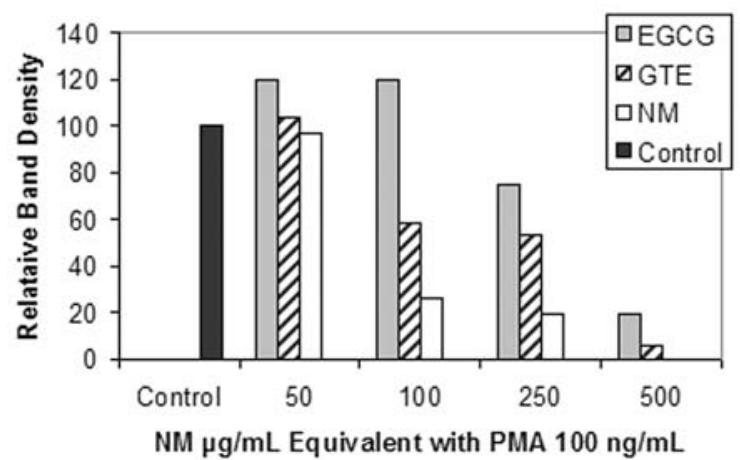

Figure 5. Comparative effects of EGCG, GTE and NM on MMP-2 and MMP-9 expression of PMA (100 ng/ml)-treated human fibrosarcoma HT-1080 cells. (A, B) Gelatinase zymogram of HT-1080 cells showing increased MMP-9 expression with PMA treatment and dose-dependent inhibition of MMP-2 and MMP-9 expression with NM, GTE and EGCG. NM was the most potent followed by GTE and EGCG. (A) Legend: 1-Markers, 2-control, 3-5, 50 $\mu \mathrm{g} / \mathrm{ml}$ NM EQ of EGCG, GTE and NM. respectively; 6-8, $100 \mu \mathrm{g} / \mathrm{ml}$ NM EQ of EGCG, GTE and NM, respectively. (B) Legend: 1-Markers, 2-control, 3-5, 250 $\mu \mathrm{g} /$ $\mathrm{ml}$ NM EQ of EGCG, GTE and NM, respectively; 6-8, $500 \mu \mathrm{g} / \mathrm{ml}$ NM EQ of EGCG, GTE and NM, respectively. (C, D) Quantitative densitometry showing comparative effects of NM, GTE and EGCG on PMA-treated HT-1080 cell (C) MMP-2 and (D) MMP-9 expression.

Table IV. Effect of EGCG, GTE and NM on MMP-2 and -9 secretion by glioblastoma T-98G.

\begin{tabular}{|c|c|c|c|c|}
\hline & \multicolumn{2}{|c|}{ Without PMA } & \multicolumn{2}{|c|}{$\begin{array}{l}\text { With PMA } \\
(100 \mathrm{ng} / \mathrm{ml})\end{array}$} \\
\hline & $\begin{array}{c}\text { MMP-2 } \\
(\%)\end{array}$ & $\begin{array}{c}\text { MMP-9 } \\
(\%)\end{array}$ & $\begin{array}{c}\text { MMP-2 } \\
(\%)\end{array}$ & $\begin{array}{c}\text { MMP-9 } \\
(\%)\end{array}$ \\
\hline \multicolumn{5}{|c|}{ EGCG $(\mu \mathrm{g} / \mathrm{ml})$} \\
\hline 0 & 100 & 100 & 100 & 100 \\
\hline 50 & 140 & 96.5 & 71 & 120 \\
\hline 100 & 29 & 98 & 0 & 120 \\
\hline 250 & 8 & 70.6 & 0 & 74.7 \\
\hline 500 & 2 & 6.2 & 0 & 19.8 \\
\hline \multicolumn{5}{|c|}{$\operatorname{GTE}(\mu \mathrm{g} / \mathrm{ml})$} \\
\hline 0 & 100 & 100 & 100 & 100 \\
\hline 50 & 143 & 93 & 70 & 104 \\
\hline 100 & 23 & 37 & 0 & 58.6 \\
\hline 250 & 11 & 33 & 0 & 53.6 \\
\hline 500 & 0 & 6.2 & 0 & 6.24 \\
\hline \multicolumn{5}{|c|}{$\begin{array}{l}\text { Nutrient mixture } \\
(\mu \mathrm{g} / \mathrm{ml})\end{array}$} \\
\hline 0 & 100 & 100 & 100 & 100 \\
\hline 50 & 109 & 95 & 0 & 96.7 \\
\hline 100 & 0 & 23.7 & 0 & 26.2 \\
\hline 250 & 0 & 7.4 & 0 & 19.5 \\
\hline 500 & 0 & 0 & 0 & 0 \\
\hline
\end{tabular}

Table V. Effect of EGCG, GTE and NM on MMP-2 and -9 secretion by uterine leiomyosarcoma (SK-UT-1).

\begin{tabular}{|c|c|c|}
\hline & \multicolumn{2}{|c|}{ With PMA } \\
\hline & $\begin{array}{l}\text { MMP-9 } \\
\text { (Inactive) }\end{array}$ & $\begin{array}{l}\text { MMP-9 } \\
\text { (Active) }\end{array}$ \\
\hline \multicolumn{3}{|c|}{ EGCG $(\mu \mathrm{g} / \mathrm{ml})$} \\
\hline 0 & 100 & 100 \\
\hline 50 & 207 & 138 \\
\hline 100 & 82.2 & 79.2 \\
\hline 250 & 28.8 & 29.5 \\
\hline 500 & 3 & 8.3 \\
\hline \multicolumn{3}{|c|}{ GTE $(\mu \mathrm{g} / \mathrm{ml})$} \\
\hline 0 & 100 & 100 \\
\hline 50 & 192 & 148 \\
\hline 100 & 79.4 & 62.5 \\
\hline 250 & 39.5 & 46.6 \\
\hline 500 & 0.0 & 1.0 \\
\hline \multicolumn{3}{|c|}{ Nutrient mixture $(\mu \mathrm{g} / \mathrm{ml})$} \\
\hline 0 & 100 & 100 \\
\hline 50 & 130 & 133 \\
\hline 100 & 57.7 & 64.8 \\
\hline 250 & 25.6 & 29.0 \\
\hline 500 & 0.0 & 0.0 \\
\hline
\end{tabular}

mixture and $100 \mu \mathrm{g} / \mathrm{ml}$ with EGCG and GTE, while MMP-9 expression was only abolished by the $\mathrm{NM}$, at $500 \mu \mathrm{g} / \mathrm{ml}$ ). 
A

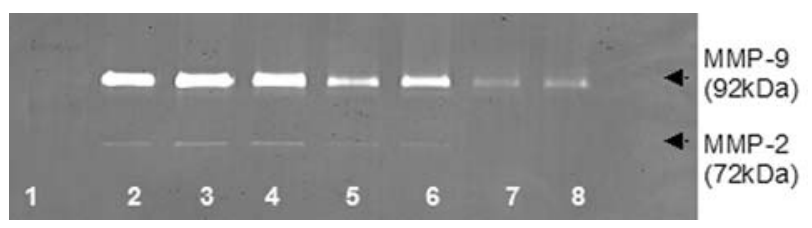

C

MMP.2

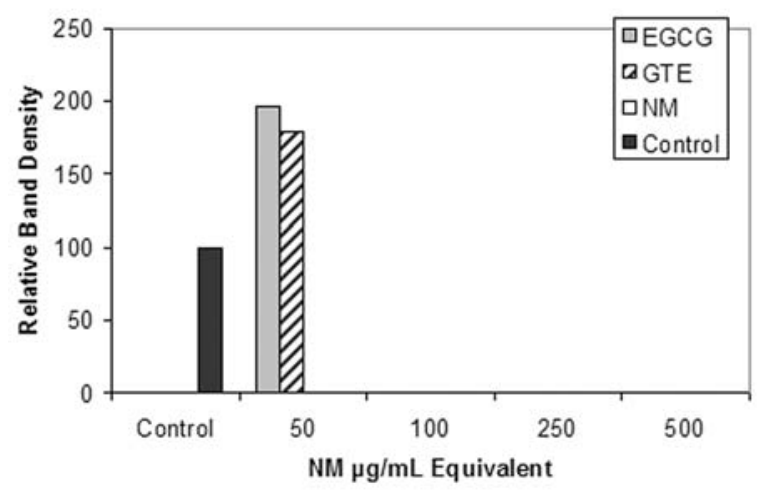

B

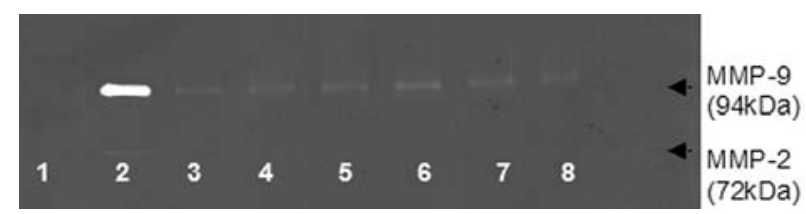

$\mathbf{D}$

MMP-9

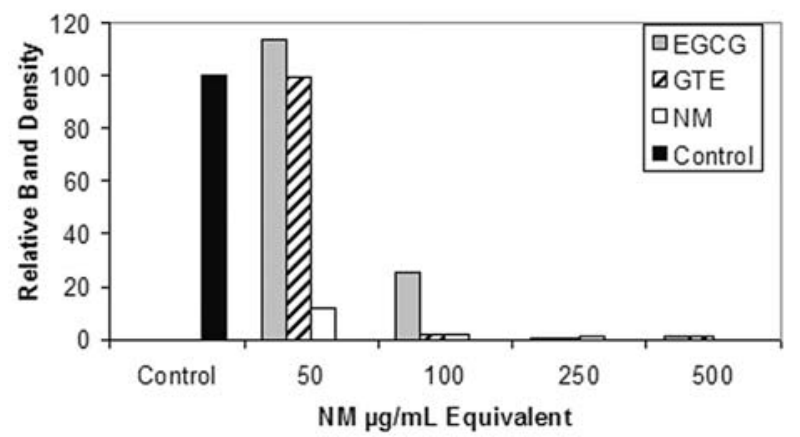

Figure 6. Comparative effects of EGCG, GTE and NM on MMP-2 and MMP-9 expression of normal human hepatocellullar carcinoma SK-Hep-1 cells. (A, B) Gelatinase zymogram of normal SK-Hep-1 cells showing dose-dependent inhibition of MMP-2 and MMP-9 expression. NM was the most potent followed by GTE and EGCG. (A) Legend: 1-Markers, 2-control, 3-5, $50 \mu \mathrm{g} / \mathrm{ml} \mathrm{NM} \mathrm{EQ} \mathrm{of} \mathrm{EGCG,} \mathrm{GTE} \mathrm{and} \mathrm{NM,} \mathrm{respectively;} \mathrm{6-8,} 100 \mu \mathrm{g} / \mathrm{ml}$ NM EQ of EGCG, GTE and NM, respectively. (B) Legend: 1-Markers, 2-control, 3-5, $250 \mu \mathrm{g} / \mathrm{ml} \mathrm{NM} \mathrm{EQ} \mathrm{of} \mathrm{EGCG,} \mathrm{GTE} \mathrm{and} \mathrm{NM,} \mathrm{respectively;} \mathrm{6-8,} 500 \mu \mathrm{g} / \mathrm{ml}$ NM EQ of EGCG, GTE and NM, respectively. (C, D) Quantitative densitometry showing comparative effects of NM, GTE and EGCG on SK-Hep-1 cell (C) MMP-2 and (D) MMP-9 expression.

A

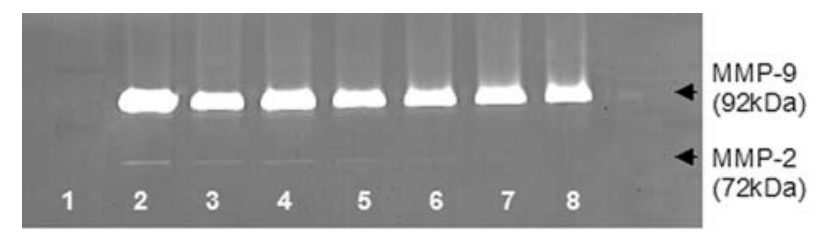

C

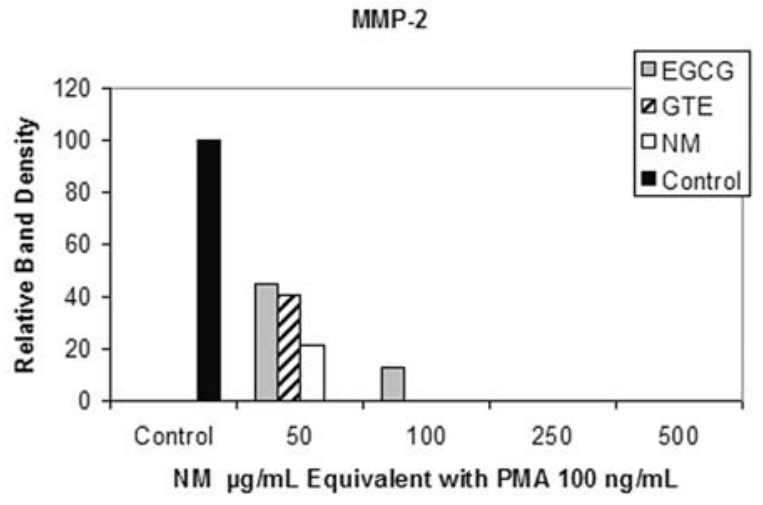

B

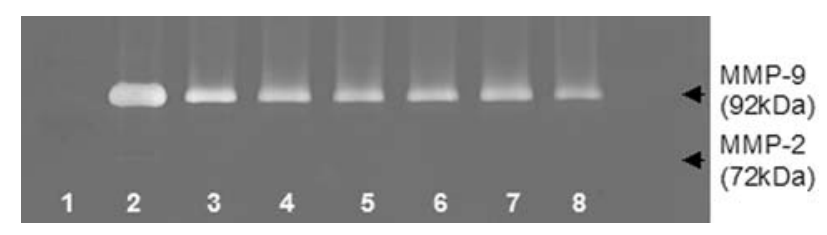

D

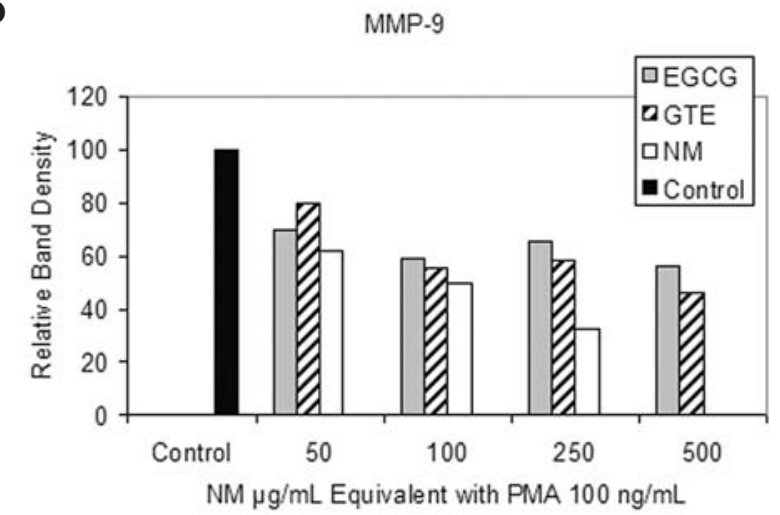

Figure 7. Comparative effects of EGCG, GTE and NM on MMP-2 and MMP-9 expression of PMA (100 ng/ml)-treated human hepatocellullar carcinoma SK-Hep-1 cells. (A, B) Gelatinase zymogram of SK-Hep-1 cells showing increased MMP-9 expression with PMA treatment and dose-dependent inhibition of MMP-2 and MMP-9 expression. NM was the most potent followed by GTE and EGCG. (A) Legend: 1-Markers, 2-control, 3-5, $50 \mu \mathrm{g} / \mathrm{ml} \mathrm{NM} \mathrm{EQ} \mathrm{of} \mathrm{EGCG,}$ GTE and NM, respectively; 6-8, $100 \mu \mathrm{g} / \mathrm{ml}$ NM EQ of EGCG, GTE and NM, respectively. (B) Legend: 1-Markers, 2-control, 3-5, 250 $\mu \mathrm{g} / \mathrm{ml} \mathrm{NM} \mathrm{EQ} \mathrm{of}$ EGCG, GTE and NM, respectively; 6-8, $500 \mu \mathrm{g} / \mathrm{ml}$ NM EQ of EGCG, GTE and NM, respectively. (C, D) Quantitative densitometry showing comparative effects of NM, GTE and EGCG on PMA-treated SK-Hep-1 cell (C) MMP-2 and (D) MMP-9 expression.

This is understandable because PMA greatly increased MMP-9 expression in fibrosarcoma cells, but not MMP-2.

The cumulative effect of EGCG, GTE, and NM on MMP expression was assessed by treating cells to increasing con- centrations of EGCG, GTE and NM, summing all the band densities within a treatment group, and comparing these densities between treatments. As shown in Table VI, cumulative MMP-2 expression of uninduced fibrosarcoma cells treated 
Table VI. Comparative cumulative expression (total band pixels in thousands) of MMP-2 and -9 in cell lines treated with EGCG, GTE and NM.

\begin{tabular}{lrrrrrr}
\hline & EGCG & \multicolumn{1}{c}{ GTE } & NM & EGCG with PMA & GTE with PMA & NM with PMA \\
\hline HT-1080 & & & & & & \\
MMP-2 & 7.88 & 7.47 & 3.29 & 0.21 & 0.20 & 0.00 \\
MMP-9 & 5.74 & 3.02 & 1.58 & 209.06 & 139.84 & 93.54 \\
SK-Hep-1 & & & & & & \\
MMP-2 & 1.21 & 1.10 & 0.00 & 0.77 & 0.55 & 0.29 \\
MMP-9 & 256.51 & 187.28 & 26.59 & 611.90 & 593.80 & 508.28 \\
T-98G & & & & & & \\
MMP-2 & 109.97 & 86.63 & 65.84 & 178.16 & 140.09 & 53.20 \\
MMP-9 & 0.17 & 0.17 & 0.10 & 92.69 & & 52.50 \\
SK-UT-1 & & & & & & \\
MMP-9 (inactive) & 0.00 & 0.00 & 0.00 & 51.36 & 49.97 & 34.30 \\
MMP-9 (active) & 0.00 & 0.00 & 0.00 & 87.42 & 87.30 & 77.95 \\
\hline
\end{tabular}

with EGCG, GTE and NM resulted in total band pixels (in thousands) of 7.9, 7.5 and 3.3, respectively, showing the significantly more modulating effect of NM. Similarly, cumulative MMP-9 expression of uninduced fibrosarcoma cells with EGCG, GTE and NM resulted in total band pixels (in thousands) of 5.7, 3.0 and 1.6, respectively. Cumulative MMP-2 and MMP-9 expression followed the same pattern with potent inhibition by NM followed by GTE and EGCG.

Effect of NM, GTE and EGCG on MMP-2 and -9 secretion by hepatocellular carcinoma cells. Hepatocellular carcinoma (SK-Hep-1) cells expressed both MMP-2 and MMP-9, but MMP-9 to a much greater extent, as shown in Fig. 6 and Table III. Our results demonstrated the nutrient mixture to be the most potent inhibitor of both MMP-2 and MMP-9, followed by green tea extract and then EGCG. The low expression of MMP-2 rendered the nutrient mixture able to fully inhibit MMP-2 expression by $50 \mu \mathrm{g} / \mathrm{ml}$, whereas green tea extract and EGCG completely blocked MMP-2 expression at $100 \mu \mathrm{g} / \mathrm{ml}$. MMP-9 expression decreased in a dosedependent fashion but was not completely abolished. However, minimal MMP-9 expression was detected at $100 \mu \mathrm{g} / \mathrm{ml} \mathrm{GTE}$ and NM and at $250 \mu \mathrm{g} / \mathrm{ml}$ EGCG treatment. PMA treatment of SK-Hep-1 further induced MMP-9 expression and left the slight expression of MMP-2 by hepatocellular carcinoma cells unchanged. The effect of the inhibitors remained the same, with the nutrient mixture being the most effective, followed by green tea extract, and then EGCG, as shown in Fig. 7 and Table III. MMP-2 expression was again abolished by $100 \mu \mathrm{g} / \mathrm{ml}$ by the nutrient mixture, and by $250 \mu \mathrm{g} / \mathrm{ml}$ by EGCG. MMP-9 expression was decreased in a dose-dependent fashion by all treatments, with the nutrient mixture being the most effective, although MMP-9 expression was not fully abolished (understandably due to the concurrent treatment by PMA).

As shown in Table VI, cumulative MMP-2 expression of uninduced hepatocelluar carcinoma cells treated with EGCG,
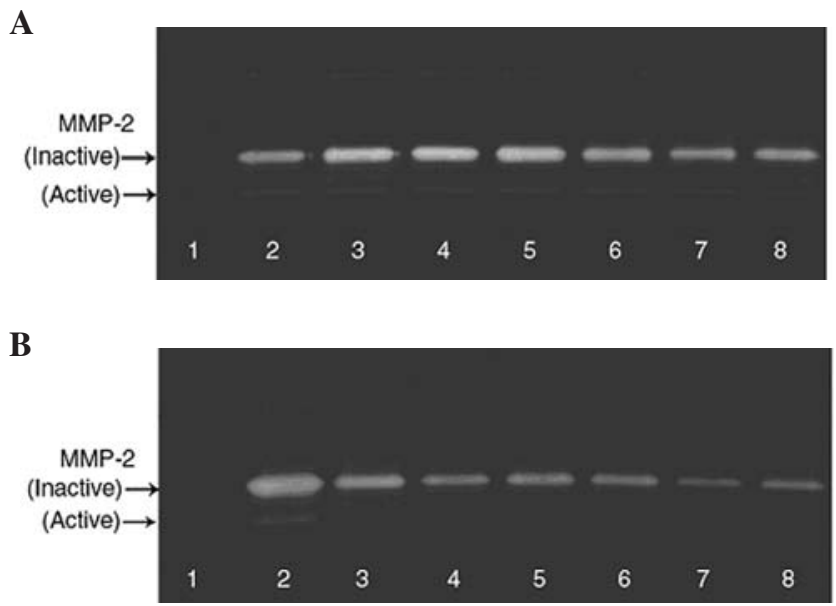

C

MMP-2

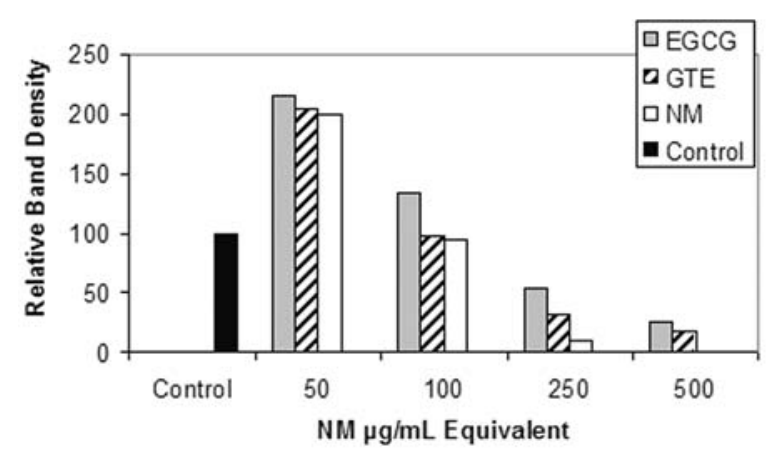

Figure 8. Comparative effects of EGCG, GTE and NM on MMP-2 and MMP-9 expression of normal human glioblastoma T-98G cells. (A, B) Gelatinase zymogram of normal T-98G cells showing secretion of only MMP-2, which was inhibited in a dose-dependent manner by all three test agents, most potently by NM. (A) Legend: 1-Markers, 2-control, 3-5, $50 \mu \mathrm{g}$ / ml NM EQ of EGCG, GTE and NM, respectively; 6-8, $100 \mu \mathrm{g} / \mathrm{ml} \mathrm{NM} \mathrm{EQ}$ of EGCG, GTE and NM, respectively. (B) Legend: 1-Markers, 2-control, 3$5,250 \mu \mathrm{g} / \mathrm{ml}$ NM EQ of EGCG, GTE and NM, respectively; 6-8, $500 \mu \mathrm{g} / \mathrm{ml}$ NM EQ of EGCG, GTE and NM, respectively. (C) Quantitative densitometry showing comparative effects of NM, GTE and EGCG on normal T-98G cell MMP-2 expression. 
A

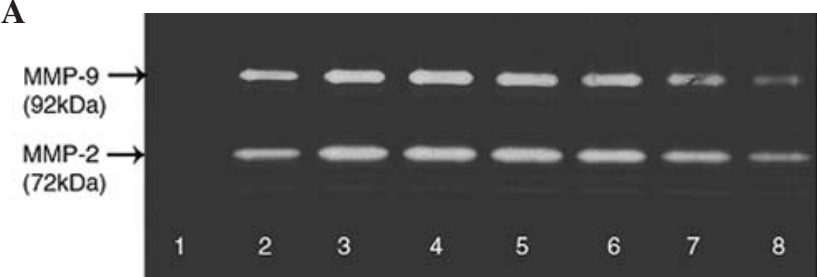

C

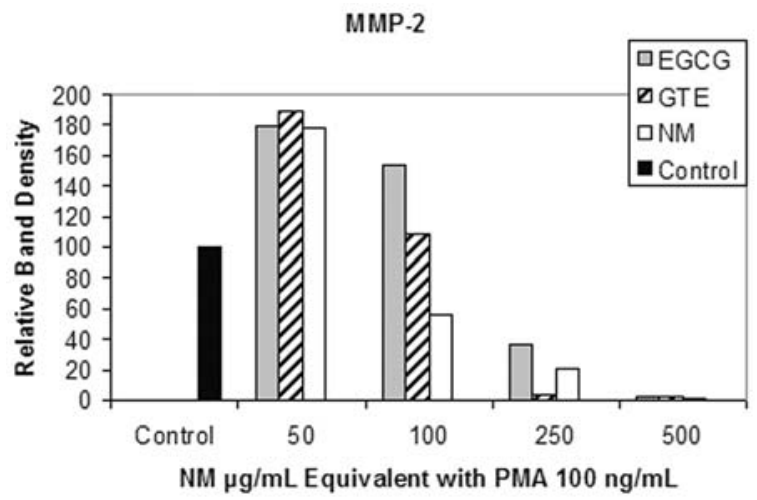

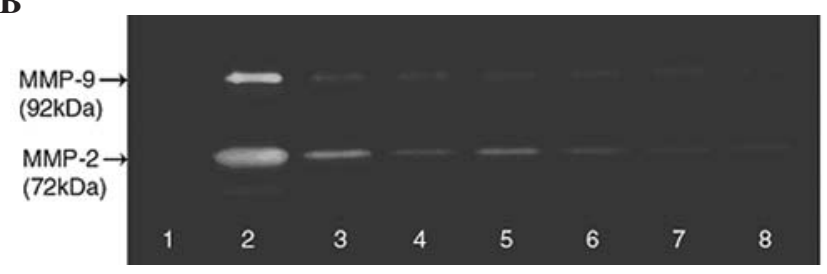

D

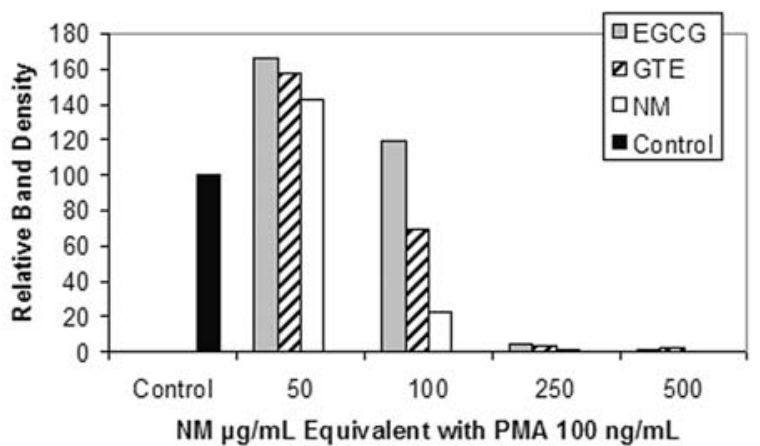

Figure 9. Comparative effects of EGCG, GTE and NM on MMP-2 and MMP-9 expression of PMA (100 ng/ml)-treated human glioblastoma T-98G cells. (A, B) Gelatinase zymogram of SK-Hep-1 cells showing induced MMP-9 expression with PMA treatment and dose-dependent inhibition of MMP-2 and MMP-9 expression. NM was the most potent followed by GTE and EGCG. (A) Legend: 1-Markers, 2-control, 3-5, 50 $\mu \mathrm{g} / \mathrm{ml} \mathrm{NM} \mathrm{EQ} \mathrm{of} \mathrm{EGCG,} \mathrm{GTE} \mathrm{and} \mathrm{NM,}$ respectively; 6-8, $100 \mu \mathrm{g} / \mathrm{ml}$ NM EQ of EGCG, GTE and NM, respectively. (B) Legend: 1-Markers, 2-control, 3-5, $250 \mu \mathrm{g} / \mathrm{ml}$ NM EQ of EGCG, GTE and NM, respectively; 6-8, $500 \mu \mathrm{g} / \mathrm{ml}$ NM EQ of EGCG, GTE and NM, respectively. (C, D) Quantitative densitometry showing comparative effects of NM, GTE and EGCG on PMA-treated T-98G cell (C) MMP-2 and (D) MMP-9 expression.

A

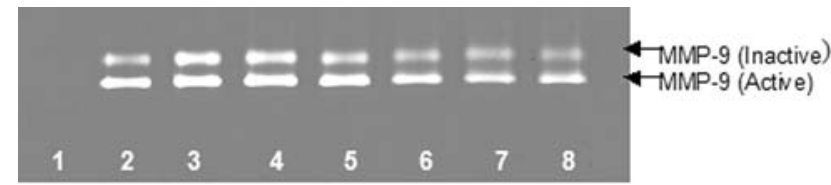

C

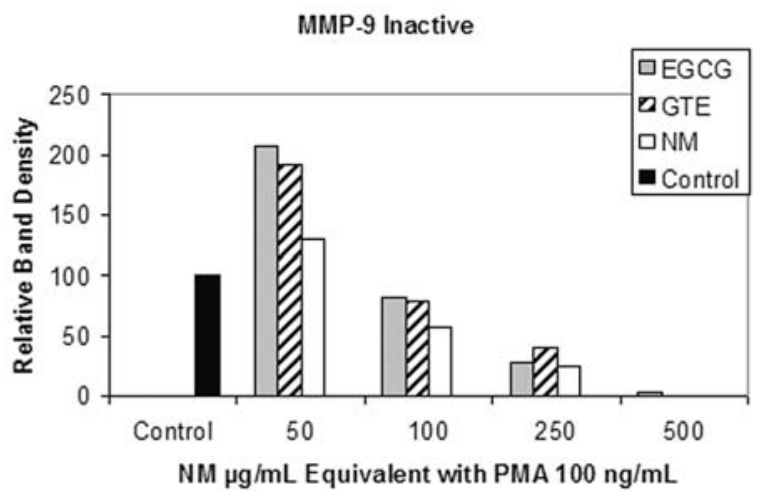

B

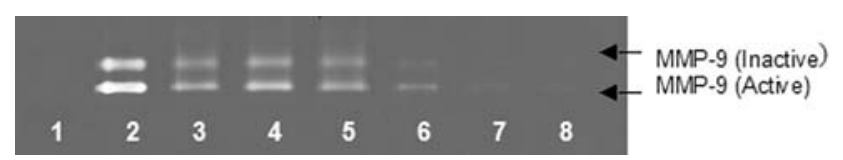

D

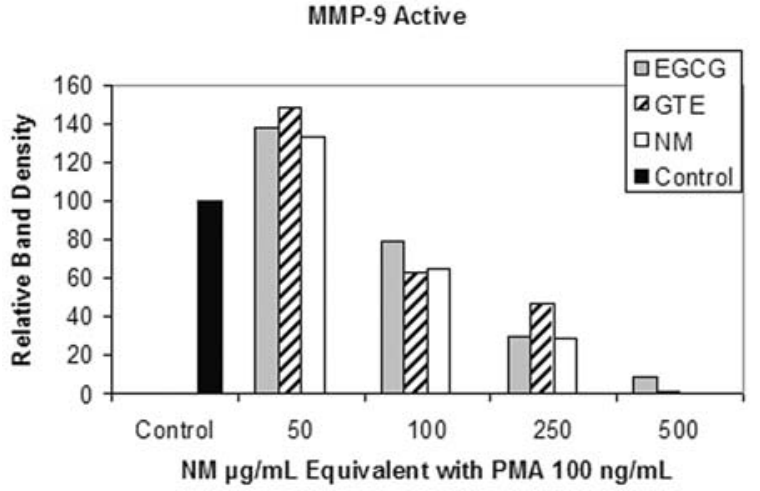

Figure 10. Comparative effects of EGCG, GTE and NM on MMP-2 and MMP-9 expression of PMA (100 ng/ml)-treated human leiomyosarcoma SK-UT-1 cells. (A, B) Gelatinase zymogram of SK-UT-1 cells showing induced secretion of MMP-9 (inactive and active), which was inhibited in a dose-dependent manner by all three test agents; NM was the most potent followed by GTE and EGCG. (A) Legend: 1-Markers, 2-control, 3-5, 50 $\mu \mathrm{g} / \mathrm{ml} \mathrm{NM} \mathrm{EQ} \mathrm{of} \mathrm{EGCG,}$ GTE and NM, respectively; 6-8, $100 \mu \mathrm{g} / \mathrm{ml} \mathrm{NM} \mathrm{EQ} \mathrm{of} \mathrm{EGCG,} \mathrm{GTE} \mathrm{and} \mathrm{NM,} \mathrm{respectively.} \mathrm{(B)} \mathrm{Legend:} \mathrm{1-Markers,} \mathrm{2-control,} \mathrm{3-5,} \mathrm{250} \mu \mathrm{g} / \mathrm{ml} \mathrm{NM} \mathrm{EQ} \mathrm{of}$ EGCG, GTE and NM, respectively; 6-8, $500 \mu \mathrm{g} / \mathrm{ml} \mathrm{NM} \mathrm{EQ} \mathrm{of} \mathrm{EGCG,} \mathrm{GTE} \mathrm{and} \mathrm{NM,} \mathrm{respectively.} \mathrm{(C,} \mathrm{D)} \mathrm{Quantitative} \mathrm{densitometry} \mathrm{showing} \mathrm{comparative}$ effects of NM, GTE and EGCG on PMA-treated SK-UT-1 cell (C) MMP-9 (inactive) and (D) MMP-9 (active) expression.

GTE and NM resulted in total band pixels (in thousands) of $1.21,1.10$ and 0 , respectively, showing the significantly more modulating effect of NM. Similarly, cumulative MMP-9 expression of uninduced fibrosarcoma cells with EGCG, GTE and NM resulted in total band pixels (in thousands) of 256.5, 187.3 and 26.6, respectively. Cumulative MMP-2 and MMP-9 expression followed the same pattern with potent inhibition by NM followed by GTE and EGCG. 
Effect of NM, GTE and EGCG on MMP-2 and -9 secretion by glioblastoma cells. Human glioblastoma (T-98G) cells expressed only MMP-2, which decreased in a dose-dependent fashion with treatment with all three test agents, but with the nutrient mixture being the most effective, as shown in Fig. 8 and Table IV. Treating T-98G with PMA induced MMP-9 expression to an equal extent to which MMP-2 was expressed. Both MMP-2 and MMP-9 expression decreased with increasing concentration of treatment, with the nutrient mixture being most effective, followed by green tea extract and then EGCG, as shown in Fig. 9 and Table IV.

As shown in Table VI, cumulative MMP-2 expression of uninduced glioblastoma cells treated with EGCG, GTE and NM resulted in total band pixels (in thousands) of 110, 86.6 and 65.8, respectively, showing the significantly more modulating effect of NM. Cumulative MMP-2 and MMP-9 expression followed the same pattern with potent inhibition by NM followed by GTE and EGCG.

Effect of NM, GTE and EGCG on MMP-2 and -9 secretion by uterine leiomyosarcoma cells. Uterine leiomyosarcoma (SK-UT-1) cells expressed no MMPs, and only MMP-9 after PMA treatment. PMA-treated SK-UT-1 cells showed a dosedependent decrease of MMP-9 expression with increasing concentration of inhibitor treatment. The most effective inhibition of MMP-9 expression was seen with the nutrient mixture, abolishing inactive and active MMP-9 expression by $500 \mu \mathrm{g} / \mathrm{ml}$, as shown in Fig. 10 and Table V.

As shown in Table VI, cumulative inactive MMP-9 expression of PMA-treated leiomyosarcoma cells treated with EGCG, GTE and NM resulted in total band pixels (in thousands) of 51.4, 50.0 and 34.3 , respectively, showing the significantly more modulating effect of NM. Cumulative active MMP-9 expression of PMA-treated leiomyosarcoma cells with EGCG, GTE and NM resulted in total band pixels (in thousands) of 87.4, 87.3 and 77.9, respectively.

In conclusion, investigation of the comparative effects of NM, GTE and EGCG on uniduced and PMA-treated cancer cell lines (fibrosarcoma, hepatocellular carcinoma, glioblastoma and leiomyosarcoma) with different patterns of MMP-2 and MMP-9 expression, demonstrated the superior inhibitory action of NM over GTE and EGCG on modulation of MMPs. The superior potency of NM over GTE and EGCG can be understood from the more comprehensive treatment offered by the combination of nutrients in NM over individual components of NM since MMP-2 and MMP-9 are mediated by differential pathways. LPA, NAC and selenium had no effect on MMP-2 and MMP-9 expression by these cancer cell lines. However, green tea and its component EGCG inhibited MMP expression but to a smaller degree than NM, which is composed of a combination of LPA, NAC, selenium and GTE. Thus NM, the mixture of all these components, demonstrated superior inhibitory activity on MMP expression from a synergistic, rather than from an additive effect. This study suggests the importance of nutrients working in cooperation to more effectively treat complex biochemical pathways.

\section{Acknowledgements}

This study was funded by the Dr Rath Health Foundation (Plantation, FL), a non-profit organization.

\section{References}

1. Fidler IJ: Molecular biology of cancer: invasion and metastasis. In: Cancer: Principles and Practice of Oncology. 5th edition. De Vita VT, Hellman S and Rosenberg SA (eds). LippincottRaven, Philadelphia, PA, pp135-152, 1997.

2. Folkman J: Role of angiogenesis in tumor growth and metastasis. Semin Oncol 29: 15-18, 2002.

3. Egeblad M and Werb Z: New functions for the matrix metalloproteinases in cancer progression. Nat Rev Cancer 2: 161-174, 2002.

4. Chambers AF and Matrisian LM: Changing views on the role of matrix metalloprotenases in metastasis. J Natl Cancer Inst 89: 1260-1270, 1997.

5. Kleiner DL and Stetler-Stevenson WG: Matrix metalloproteinases and metastasis. Cancer Chemother Pharmacol 43 (Suppl.): S42S51, 1999.

6. Sakamoto Y, Mafune K, Mori M, Shiraishi T, Imamura H, Mori M, Takayama T and Makuuchi M: Overexpression of MMP-9 correltaes with grwoth of small hepatocellular carcinoma. Int J Oncol 17: 237-243, 2000.

7. Kashiwagi A: Matrix metalloproteases in hepatocellular carcinoma. A study in resected specimens from 25 patients. Tokyo Jikekai Med J 118: 33-48, 2001.

8. Ozen O, Krebs B, Hemmerlein B, Pekrun A, Kretzschmar H and Herms J: Expression of matrix metalloproteinases and their inhibitors in medulloblastoma and their prognostic relevance. Clin Cancer Res 10: 4746-4753, 2004.

9. Loppä S, Saarto T, Vehmanen L, Blomqvist C and Elomaa I: A high serum matrix metalloproteinase-2 level is associated with an adverse prognosis in node-positive breast carcinoma. Clin Cancer Res 10: 1057-1063, 2004.

10. Stearns M and Stearns ME: Evidence for increased activated metalloproteinase-2 (MMP-2a) expression associated with human prostate cancer progression. Oncol Res 8: 69-75, 1996.

11. Sato T, Sakai T, Noguchi Y, Takta M, Hirakawa S and Ito A: Tumor-stromal cell contact promotes invasion of human uterine cervical carcinoma cells by augmenting the expression and activation of stromal matrix metalloproteinases. Gynecol Oncol 92: 47-56, 2004.

12. Di Nezza LA, Misajon A, Zhang J, Jobling T, Quinn MA, Ostör AG, Nie G, Lopata A and Salamonsen LA: Presence of active gelatinases in endometrial carcinoma and correlation of matrix metalloproteinase expression with increasing tumor grade and invasion. Cancer 94: 1466-1475, 2002.

13. Roomi MW, Monterrey JC, Kalinovsky T, Rath M and Niedzwiecki A: In vitro modulation of MMP-2 and MMP-9 in human cervical and ovarian cancer cell lines by cytokines, inducers and inhibitors. Oncol Rep 23: 605-614, 2010.

14. Roomi MW, Monterrey JC, Kalinovsky T, Rath M and Niedzwiecki A: Modulation of MMP-2 and MMP-9 by cytokines, mitogens and inhibitors in lung cancer and malignant mesothelioma cell lines. Oncol Rep 22: 1283-1291, 2009.

15. Roomi MW, Roomi N, Ivanov V, Kalinovsky T, Niedzwiecki A and Rath M: Inhibitory effect of a mixture containing ascorbic acid, lysine, proline and green tea extract on critical parameters in angiogenesis. Oncol Rep 14: 807-815, 2005.

16. Roomi MW, Ivanov V, Kalinovsky T, Niedzwiecki A and Rath M: Inhibition of pulmonary metastasis of melanoma $\mathrm{B} 16 \mathrm{FO}$ cells in C57BL/6 mice by a nutrient mixture consisting of ascorbic acid, lysine, proline, arginine and green tea extract. Exp Lung Res 32: 517-530, 2006.

17. Roomi MW, Ivanov V, Kalinovsky T, Niedzwiecki A and Rath M: In vivo and in vitro antitumor effect of ascorbic acid, lysine, proline, arginine and green tea extract on human fibrosarcoma cells HT-1080. Med Oncol 23: 105-112, 2006.

18. Rath $\mathrm{M}$ and Pauling L: Plasmin-induced proteolysis and the role of apoprotein(a), lysine and synthetic analogs. Orthomolecular Med 7: 17-23, 1992.

19. Sun Z, Chen YH, Wang P, Zhang J, Gurewich V, Zhang P and Liu JN: The blockage of high-affinity lysine binding sites of plasminogen by EACA significantly inhibits prourokinaseinduced plasminogen activation. Biochem Biophys Acta 1596: 182-192, 2002.

20. Valcic S, Timmermann BN, Alberts DS, Wachter GA, Krutzsch M, Wymer J and Guillen JM: Inhibitory effect of six green tea catechins and caffeine on the growth of four selected human tumor cell lines. Anticancer Drugs 7: 461-468, 1996. 
21. Demeule M, Michaud-Levesque J, Annabi B, Gingras D, Boivin D, Jodoin J, Lamy S, Bertrand Y and Béliveau R: Green tea catechins as novel antitumor and antiangiogenic compounds. Curr Med Chem Anticancer Agents 2: 441-463, 2002.

22. Hara Y: Green Tea: Health Benefits and Applications. Marcel Dekker, Basel, New York, 2001.

23. Mukhtar $\mathrm{H}$ and Ahmed N: Tea polyphenols: prevention of cancer and optimizing health. AM J Clin Nutr 71: S1698-S1702, 2000.

24. Yang GY, Liao J, Kim K, Yurtow EJ and Yang CS: Inhibition of growth and induction of apoptosis in human cancer cell lines by tea polyphenols. Carcinogenesis 19: 611-616, 1998.

25. Taniguchi S, Fujiki H, Kobayashi H, Go H, Miyado K, Sadano H and Shimikawa R: Effect of (-) epigallocatechin gallate, the main constituent of green tea, on lung metastasis with mouse B16 melanoma cell lines. Cancer Lett 65: 51-54, 1992.

26. Wang X, Hao MW, Dong K, Lin F, Ren JH and Zhang HZ: Apoptotsis induction effects of EGCG in laryngeal squamous cell carcinoma cells through telomerase repression. Arch Pharm Res 32: 1263-1269, 2009

27. Kawakami S, Kageyama Y, Fujii Y, Kihara K and Oshima H: Inhibitory effects of N-acetyl cysteine on invasion and MMP 9 production of T24 human bladder cancer cells. Anticancer Res 21: $213-219,2001$
28. Morini M, Cai T, Aluigi MG, et al: The role of the thiol Nacetyl cysteine in the prevention of tumor invasion and angiogenesis. Int J Biol Markers 14: 268-271, 1999.

29. Yoon SO, Kim MM and Chung AS: Inhibitory effects of selenite on invasion of HT 1080 tumor cells. J Biol Chem 276: 20085-20092, 2001.

30. Rayman MP: Selenium in cancer prevention: a review of the evidence and mechanism of action. Proc Nutr Soc 64: 527-542, 2005.

31. Schrauzer GN: Anticarcinogenic effects of selenium. Cell Mol Life Sci 57: 1864-1873, 2000.

32. Yeom CH, Lee G, Park JH, Yu J, Park S, Yi SY, Lee HR, Hong YS, Yang J and Lee S: High-dose concentration administration of ascorbic acid inhibits tumor growth in BALB/C mice implanted with sarcoma 180 cancer cells via restriction of angiogenesis. J Transl Med 7: 70, 2009.

33. Maramag C, Menon M, Balaji KC, Reddy PG and Laxmanan S: Effect of vitamin $\mathrm{C}$ on prostate cancer cells in vitro: effect on cell number, viability and DNA synthesis. Prostate 32: 188-195, 1997.

34. Cooke JP and Dzau VJ: Nitric oxide synthase: role in the genesis of vascular disease. Annu Rev Med 48: 489-509, 1997. 